\title{
N. Mygind
}

I.M. Gwaltney Ir

B. Winther

I. Owen Hendley

Authors' affiliations:

N. Mygind, Department of Respiratory Diseases, University Hospital of Aarhus, Aarhus, Denmark I.M. Gwaltney, Ir, B. Winther, I. Owen Hendley, Division of Epidemiology and Virology, Hcalth Sciences Center, University of Virginia, Charlottesville, Virginia, USA

Correspondence to: Niels Mygind $M D$

Department of Respiratory Discases

University Hospital of Aarhus

DK-80oo Aarhus Denmark
Date:

Accepted for publication 13 August 1998

To cite this article

Mygind N., Gwaltney Ir. I.M., Winther B. 4 Owen Hendley $/$. The common cold and asthma.

Allergy 1999, 54, Suppl 57, 146-159.

Copyright: Munksgard 1990

ISSN $0105-4538$

\section{The common cold and asthma}

\section{Introduction}

This review focuses on how a viral infection and disease of the upper airways can influence asthma, a disease of the lower airways. We will, therefore, discuss "the common cold", which is caused predominantly by rhinovirus [RV\} and coronavirus, and we will not deal with a general airway infection ("flu"), caused by influenza-, parainfluenza- and adenovirus, because these viruses may trigger asthma predominantly by a direct infection of bronchial cells.

The common cold is, as indicated by the name, a very frequent disease. In otherwise healthy persons it is a trivial disorder, although it causes considerable morbidity, absence from school and work, and complications such as bacterial otitis media and sinusitis. Common cold viruses frequently trigger acute exacerbations of asthma and of chronic obstructive lung disease. In patients with chronic lung diseases a common cold often has serious consequences, resulting in considerable morbidity and increased mortality.

Obviously, the common cold is a key disease in this supplement on "The nose and paranasal sinuses in asthma". Considering the paramount importance of a viral airway infection for asthma morbidity it is surprising that relatively few studies have investigated the nature of the link between a common cold/an RV infection and asthma.

Below we will give an overview of the published literature on the common cold and asthma but we will also refer to recent review articles by Holgate (1), Johnston (2) and Busse (3). These scientists have initiated most of the recent work on the link between the common cold and asthma. We shall begin, however, with a description of the pathophysiology of the common cold/RV infection, its transmission and its treatment, because knowledge of these issues is of importance for a full understanding of the link between common 
cold and asthma, and possibly for future attempts of preventing cold-induced asthma exacerbations.

\section{Rhinovirus colds and naturally acquired colds}

\section{Virology}

In textbooks and review articles RV is described as being responsible for $50-60 \%$ of acute viral upper respiratory illnesses, and coronavirus for about $10-20 \%$, while influenza virus, parainfluenza vinus, adenovirus and respiratory syncytial virus (RSV) account for a minor proportion of common colds (4). A recent study, using the sensitive reverse transcription polymerase chain reaction (RT-PCR) technique, however, has shown RV to be relatively more important and have identified this virus in $80 \%$ of adults with cold symptoms during the autumn $(5)$.

$\mathrm{RV}$ is one of the most well-described vinuses on the molecular level (4). It is a nonenveloped, 30-nanometer RNA particle (picornavirus). The surface of the virus has deep canyons, containing the ligand for the RV receptor on the epithelial cells, which is intercellular adhesion molecule-1 (ICAM-1) (5) (see later).

$\mathrm{RV}$ has more than 100 immunotypes. Infection with each type provides immunity, but vaccination is not realistic due to the considerable antigen diversity (4).

\section{Transmission of rhinovirus}

Introduction of RV into the eye or the nose is a highly efficient way of initiating an experimental infection. By contrast, inoculation of RV into the mouth or exposure to infected volunteers, for example by prolonged kissing, is an inefficient method of initiating infection $(6)$.

Children are the major reservoir for RV. Young children experience about eight colds a year, while adults have one to two colds (7). In addition, children easily acquire a runny nose as they have the same number of mucous glands as adults, but a smaller mucosal area and therefore a lower mucociliary transport capacity. Consequently, transmission occurs readily in families with young children $(6,8)$, especially when they attend kindergartens. Such children are "toxic".

During colds, nasal secretions containing RV, contaminate the fingers and the environment of the infected person. $\mathrm{RV}$ retains infectivity for up to 3 days, for example, on plastic surfaces (6).
Attempts to transmit RV infection by experimental exposure have shown that a 15-s hand-to-hand contact between a virus-infected and an antibody-negative person followed by touching the eye or the nostril, is a very efficient way to transmit RV (9).

The hand contact-self inoculation model has been used to test virucidal hand treatment $(10)$, environmental disinfectants (11) and virucidal nasal tissues (12). The findings in these studies support the finger-to-eye and finger-to-nose inoculation routes of cold transmission, and they indicate that stopping virus transmission may be one way to reduce the number of cold-induced asthma exacerbations.

\section{Initial infection of cells, shedding and spread of rhinovirus}

As mentioned above, the portal of entry for RV can be either the eye or the nose, where the virus can be placed by a finger during eye nubbing and nose picking, respectively. The relative importance of these two sites of entry, in different age groups, is unknown. Is is an open question whether the lower airways can be infected by RV and if so, whether it is by direct inhalation or by spread of infectious secretions from the nose (13) (see later).

When virus is placed in the nostril it comes into direct contact with skin or with squamous epithelium in the mucous membrane. It does not seem to be possible for a finger to reach the ciliated epithelium, which can transport the virus to the adenoid area, where infection appears to be initiated (see later). One can speculate, however, that a few virus particles, placed in the nostril, are carried to the ciliated epithelium by the sniffing of nasal secretions, running to the nostrils. Cold air induces glandular hypersecretion by a cholinergic reflex (14), which may explain why it is commonly believed that exposure to cold air predisposes to the development of an infectious common cold, or in other words why "a cold is called a cold".

When RV is placed in the eye it will pass through the nasolacrimal duct to the nasal cavity, apparently without infecting the epithelial cells in the conjunctiva, which is difficult to understand because the receptor for RV, ICAM-1 can be upregulated in conjunctival cells \{see later\}. In a study of the spread of $R V$, we inoculated virus in conjunctiva on one side. Virus could then be detected in brush biopsy samples from the nasopharyngeal mucosa earlier, more frequently, and for longer (up to 3 weeks) than in samples from the nasal cavities (15). The more frequent detection of virus in the nasopharynx than in the nose may be simply because the nasopharynx is the endpoint of the mucociliary 
clearance from the nasal passages. On the other hand, RV replication has been demonstrated by in situ hybridization in surface cells, probably $M$ cells, in the lymphoepithelium of the adenoids (16). This indicates that the adenoid may hold a key position regarding initial RV infection.

$\mathrm{RV}$ replication occurs, in ciliated and in nonciliated columnar epithelial cells, in the nasopharynx and in the nasal passages, and the newly formed viruses are shed into respiratory secretions $(17,18)$. However, the number of infected epithelial cells seems to be low. Turner and colleagues (18), utilizing immunohistochemical staining of sloughed epithelial cells from patients with experimental RV-induced colds, found that less that $2 \%$ of the cells were positive for RV antigen. By in situ hybridization, Bardin and coworkers $(19)$ found $R V$ replication in a few cells in nasal biopsies from only half the patients with RV-induced colds. Arruda and coworkers $(16,17)$ examined multiple nasal scrape biopsies from volunteers with colds and demonstrated RV replication in only a few cells, providing further evidence for virus infection in a limited number of epithelial cells. In two studies, Winther and coworkers $(15,20)$ took several brush biopsies and found vinus growth in only a part of the biopsies, showing that the RV infection of the nasal lining is not universal but "spotty".

\section{ICAM-1 is the major receptor for rhinovirus}

It is of considerable interest that the receptor for $90 \%$ of the RV types is ICAM-1 (21). Conjunctival cells and columnar epithelial cells in the nose do not constitutively express ICAM-1 but they do so when they are antigen-stimulated, for example by allergen exposure of IgE-sensitized individuals (22). One could therefore speculate that antigenstimulated persons are particularly susceptible to $\mathrm{RV}$ infections. However, it is an important counterargument that almost all normal seronegative volunteers can be infected by an experimental inoculation of RV (4). It is our hypothesis that ICAM-1 receptors in the nasopharynx hold a key position in the initial contact between virus and host cells, as cells with constitutively high ICAM-1 expression have been demonstrated on the surface of the normal adenoid (23).

As in the nose, ICAM-1 is not constitutively expressed by surface epithelial cells in the bronchi, but it is upregulated in symptomatic asthma (24). In theory, this could make asthmatic bronchial airways more sensitive than normal airways to direct infection with RV.

\section{Viral cytopathologic effect}

The effect of cold viruses on nasal epithelial cells has been studied in vitro by Winther and coworkers (25). Experimental infection with $\mathrm{RV}$ and with coronavirus does not result in visual damage to the epithelial cells. The cilia continue to beat on the nasal tissue fragments (26) and the nasal epithelial cell monolayer remains confluent (27). Thus, RV has no or a negligible cytopathologic effect on ciliated cells.

In contrast, infection of nasal cultures with influenza- and adenovirus results in a complete destruction of the epithelial cells within a few days $(25,26)$. Infection with RSV has an intermediate position (27).

One can speculate that there are two explanations of the differences between a common cold (symptoms predominantly from the upper airways) and a flu (symptoms from the entire airways|. Hypothesis 1: a cold is caused by viruses, infecting only the upper airways, while a flu is due to a virus infection of the entire airways. Hypothesis 2: a common cold is caused by viruses having no or little cytopathologic effect, while a flu is due to viruses which damage the epithelial lining. Probably the last hypothesis is most likely.

\section{Cellular inflammatory changes}

The first study of nasal histology in naturally occurring colds dated from 1930. In this work, substantial separation and sloughing of the nasal epithelium was reported (28). Based largely on this study, it was assumed for more than 50 years that the cold viruses damage the nasal epithelial lining, directly causing the cold symptoms, and also impairing mucociliary clearance, resulting in a secondary bacterial infection with neutrophilia and purulent secretions.

It was not until 1984 that a subsequent study was published using light and scanning electron microscopy (29). This study showed a largely intact and continuous epithelial surface. There was accumulation of neutrophils in spite of the absence of a concommitant bacterial infection (30). Based on these observations, we hypothesized that the virus infection of the epithelial cells causes the neutrophilia and the cold symptoms indirectly by the release of a series of inflammatory cytokines and mediators, predominantly from the epithelial cells. This hypothesis is supported by the in vitro studies, mentioned above, which show that RV does not cause any gross damage of the epithelial cells $(25)$. 


\section{Ciliated epithelial cells}

Nasal biopsies from patients with naturally acquired colds $(29,31)$ have shown an intact and continuous epithelium by light and by scanning electron microscopy. Considering the dynamics of airway epithelium, showing closure of cell defects within minutes after trauma $(32)$, these findings do not exclude an increased turnover rate and shedding of epithelial cells during a RV cold. In fact, in a study of naturally acquired colds, Pedersen and coworkers $(33)$ found a reduced number of ciliated cells in nasal scrape biopsies during and for some weeks after a naturally occurring cold. It is possible that this study was undertaken during a period with an epidemic of influenza-, parainfluenza or adenovirus infection. This study of naturally acquired colds ("wild colds") needs confirmation with the use of modern diagnostic tests for establishing the virus etiology, because the results differ strikingly from the in vitro studies showing no or very little cytopathologic effect of $\mathrm{RV}$ and coronavirus on ciliated cells. However, also some early studies of nasal smears from patients with naturally acquired colds have shown shedded ciliated cells with signs of damage ("ciliocytophthoria") (34).

The apparent contradiction between the findings of viable epithelial cells in in vitro studies of RV infection and the reduced mucociliary clearance in in vivo studies of naturally acquired colds may be explained by a transmission electron microscopic study by Afzelius (35). Among hundreds of nasal biopsies he found a single biopsy with infection of the columnar cells with a virus (coronavirus?). The infected cells looked viable without destruction, but the cilia were retracted from the surface into the cytoplasm.

\section{Neutrophils}

In our first study of naturally acquired colds, the number of neutrophil leukocytes was clearly increased in the surface epithelium and in the lamina propria very early during the disease (day 2) (29).

In experimental $R V$ infection the results are less obvious. While one study showed a slightly increased number of neutrophils in nasal biopsies on days 1 and 2 of infection (36), another study (37) failed to show any change in the number of neutrophils on day 4 of the illness.

Infiltration of neutrophils into (and through) the nasal mucosa seems to be an early and transient event. Within $24 \mathrm{~h}$ of RV inoculation Naclerio and coworkers (38) found an increase of neutrophils in nasal washes obtained every $4 \mathrm{~h}$ around the clock, and the number had already begun to decrease by day 3. An increased number of neutrophils was found by Levandowsky and coworkers $(39)$ in nasal washes from patients with experimental RV colds on day 4 after virus inoculation.

It is important to include sham-inoculation in these type of studies because a biopsy procedure in itself can induce neutrophilia, probably by pertubation of epithelial cells and subsequent release of IL-8 (36).

Experimental RV infection is associated not only with an increase in neutrophils in the nose but also in the blood 140 , 41).

\section{Mast cells and eosinophils}

Studies have shown no changes in the number of mast cells and eosinophils in the nasal epithelium and lamina propria during a cold $(29,37)$. This suggests that these cells are not involved in the pathogenesis of a common cold. However, it cannot be excluded that an RV common cold enhances allergen-induced degranulation of basophils and mast cells, as interferon released by peripheral blood cells, incubated with virus, promotes basophil histamine release (3). In addition, antihistamines have an effect on common cold symptoms (see later).

\section{Lymphocytes}

The lymphocytes in lamina propria of the nasal mucous membrane have been examined by immunohistochemistry in two studies of RV colds $(37,42)$. No changes in the total number of the cells or in the lymphocyte subsets $\left(\mathrm{CD}_{3}{ }^{+}\right.$, $\mathrm{CD}_{4}{ }^{+}, \mathrm{CD}_{8}{ }^{+}, \mathrm{CD}_{22}{ }^{+}$) were detected.

Therefore, any change in the number of circulating lymphocytes does not seem to be caused by a changed recruitment of lymphocytes to the upper airways. Possibly, the finding may reflect lymphocyte homing to the lower airways during a cold (see later).

The published data on the number of circulating lymphocytes in experimental RV infection are conflicting. In three studies $(39-41)$, the numbers of $T$ cells was reduced early during the infection. Winther and coworkers (42), on the other hand, did not find any change in $\mathrm{CD}_{3}{ }^{+}, \mathrm{CD}_{4}{ }^{+}$, $\mathrm{CD}^{+}, \mathrm{CD}_{22}{ }^{+}$(B cells) and $\mathrm{CD}_{57}{ }^{+}$(natural killer cells). Skoner and coworkers $(43)$ found an increased number of both total lymphocytes, and of the $\mathrm{CD}_{4}{ }^{+}$and $\mathrm{CD} 8^{+}$ subsets.

Interestingly, a recent study by Vianna and coworkers (44) has shown a decreased peripheral blood $T$-cell response to phytohemagglutinin and a reduced cytokine formation during a common cold (clinical diagnosis). One can speculate that this reduced $T$-cell activity may be part of the explanation why common colds induce complications such as acute otitis media, sinusitis, activation of herpes, 
exacerbations of asthma and chronic obstructive lung disease.

\section{Proinflammatory cytokines and inflammatory mediators}

RV primarily infect the nasal epithelial cells and this triggers the synthesis and release of cytokines and mediators, causing a cascade of inflammatory reactions which are assumed to be responsible for the cold symptoms $(45,46)$.

\section{Cytokines}

The cytokines, which function as neutrophil chemoattractants and activators, are of particular interest since the number of neutrophils in nasal lavage fluid is increased and the number of neutrophils correlates with symptoms in experimental RV colds (38). In this respect, IL-8 is of the greatest importance, as it is a strong chemoattractant for neutrophils and it also activates the cells.

In vitro studies of cell cultures have shown that an $\mathrm{RV}$ infection induces IL-8 production in both epithelial cells 147 , 48 and in fibroblasts (49). In vivo studies of naturally acquired colds $(50,51)$ and of experimental RV colds (52) have shown an increased level of IL- 8 in nasal lavage fluid.

Also, infection with RSV induces significant IL-8 production in epithelial cells both in the nose $(51)$ and in the bronchi $(52)$.

Viral infections stimulate the release of other cytokines (IL-1 $\beta$, IL-6, tumor necrosis factor- $\alpha$, interferon- $\gamma$ ) into nasal secretions $(50,51,53-59)$ but their role in the pathogenesis of the common cold is not clear. Interferon $-\gamma$ probably plays an important role in terminating the virus infection. IL-6 may be important in stimulating $T$ lymphocytes $(60)$. It has been shown that IL- 6 and IL- 8 are generated following vinusinduced activation of the transciption factor NF- $\mathrm{KB}(56)$.

One study of nasal lavage fluid has shown a different cytokine profile in experimental colds (interferon- $\gamma$ and IL-1 $\beta$ ) and in allergic rhinitis (GM-CSF and $I L-1 \beta)(61)$. Further studies are needed to characterize the cytokine/chemokine profile of RV-induced infection.

\section{Kinins}

Kinin levels are increased in nasal lavage fluid from patients with experimental (38) and with natural RV colds (62). The concentration of kinins peaks at the same time as the symptoms.

Intranasal challenge with bradykinin in normal subjects produces rhinorrhea, nasal obstruction and a sore throat 163 . As these symptoms imitate common cold symptoms, it provides suggestive evidence that kinins might contribute to the symptomatology of viral colds. However, a possible causal role for kinins in the development of cold symptoms cannot be established until it is possible to block their action by specific drugs.

\section{Histamine}

There is no histologic evidence of mast cell degranulation during a common cold (29), and the level of histamine in nasal lavage fluid is not increased during an experimental RV infection (64-66).

The usefulness of $\mathrm{H}_{1}$ antihistamines for the treatment of common cold has been the subject of controversy (67). However, there are now three double-blind, placebocontrolled and randomized studies with adequate statistical power which show a beneficial effect of antihistamines on cold symptoms $(68-70)$. The findings of a significant effect on sneezing, less effect on rhinorrhea and no effect on blockage speak in favor of an $\mathrm{H}_{1}$ receptor blockage being the mode of action, because this is the same symptom profile seen in the treatment of allergic rhinitis.

\section{Leukotrienes}

Sulfido-leukotrienes, sprayed into the nose, induce vascular changes (71) and they also act as secretogogues $(72)$. It is possible that drugs that inhibit the synthesis of leukotrienes and drugs that block the leukotriene receptor might have some beneficial effect on nasal blockage and mucus hypersecretion in colds. This hypothesis can now be tested as leukotriene receptor antagonists are commercially available.

\section{Prostaglandins}

Intranasal challenge with prostaglandin $D_{2}$ and with prostaglandin $F_{2 \alpha}$ results in sneezing and coughing (73). The role played by prostaglandins in the common cold can be judged by the clinical effect of NSAIDs. These drugs seem to have some beneficial effect on coughing (74) and on sneezing, but not on blockage, and there seems to be a negative effect on rhinorrhea (75).

\section{Nasal hyperresponsiveness}

Several reports have shown that a common cold may increase the nonspecific bronchial responsiveness in asthma \{see later). The possibility that a viral infection of the nose also produces nasal hyperresponsiveness, however, has not received much attention.

Grønborg and colleagues (76) performed nasal challenges with histamine and methacholine during and after a 
naturally acquired cold. Both the sneezing and the secretory response to histamine were significantly increased but only during the first 3 days of the disease, while the secretory response to methacholine was increased for 9 days. In a study of experimental RV infection Doyle and coworkers (77) also found an increased nasal responsiveness to histamine challenge for sneezing and rhinorrhea but not for blockage. While the mean number of histamine-induced sneezes increased from 4.5 to 10.5 in nonallergic volunteers, the increase in allergic rhinitis patients /studied outside the pollen season) was from 10.0 to 19.5 .

Greiff and coworkers (78) measured histamine-induced mucosal exudation of plasma before and during a coronavirus infection. The concentration of plasma components in nasal lavage fluid was significantly increased during the infection, indicating the existence of an exudative hyperresponsiveness. These authors also studied the permeability of the mucous membrane from the lumen to the tissue. In contrast to common belief, the permeability, measured as the ability to absorb ${ }^{51} \mathrm{Cr}$-EDTA, was not increased during the viral infection.

\section{Involvement of the paranasal sinuses}

A study of naturally acquired viral rhinitis using CT scan imaging showed somewhat surprisingly extensive abnormalities in the paranasal sinuses in $87 \%$ of patients in the 3-5 days after onset of nasal symptoms (79). The abnormalities resolved spontaneously without antibiotics within 3 weeks.

The CT abnormalities, which consisted of opacities in the ostiomeatal complex and paranasal sinuses, may have been due either to accumulation of mucus, to mucosal congestion/edema, or to both. The presence of air bubbles in the opacities indicates an accumulation of mucus. It is difficult to explain the occurrence of air bubbles without assuming that the secretion is blown into the sinuses from the nasal cavity. If such a mechanism is at work for introducing secretions into the sinus cavities, viruses and bacteria may follow the same route. Recent experimental data support this hypothesis.

\section{Treatment of the common cold}

Therapy of a common cold has three purposes: 1) to reduce symptoms; 2) to decrease viral shedding and spread of the infection; and 3) to prevent complications, i.e. bacterial sinusitis and otitis media, and exacerbations of asthma and of chronic obstructive lung disease.
Interferon- $\alpha$

Interferon- $\alpha$ has antiviral activity against RV. Prophylactic intranasal administration, beginning when one family member developed cold symptoms, reduced the risk of acquiring a cold by $80 \%$ among other family members (80). When used in the initial phase of a cold, intranasal interferon- $\alpha$ decreased RV shedding but it had little effect on alleviating the symptoms $(81)$. The reason for the limited symptomatic response to interferon $\alpha$, in spite of the antiviral effect, may be because the viral infection already had triggered the inflammatory cascade, responsible for the cold symptoms.

\section{Corticosteroids}

A series of cytokines are upregulated in the common cold, and the important IL- 8 is generated followed virus-induced activation of NF- $\mathrm{kB}(56)$. Corticosteroids interact with this transcription factor and can, in theory, be expected to have an anti-inflammatory effect and to be useful for symptomatic treatment of the common cold. However, in practice corticosteroids are only marginally effective on cold symptoms. In one study intranasal corticosteroid treatment, begun prior to RV inoculation, showed trends towards fewer symptoms during the first 2 days, but this was followed by a normal progression of manifestations of the common cold 182). In another study, a high dose of intranasal corticosteroid had no clinically recognizable effects on the symptoms of a naturally acquired cold, but it produced prolonged shedding of viable RV (83). Oral prednisone (60 mg daily) did not improve cold symptoms in volunteers with experimental induced RV colds but it did produce increased viral shedding (83).

It is difficult to explain why corticosteroids have no or little symptomatic effect in the common cold /a cytokinedriven neutrophil-dominated inflammatory diseasel, while these drugs have a marked effect in allergic rhinitis a cytokine-driven eosinophil-dominated inflammatory disease), considering that NF- $\mathrm{kB}$ seems to be a pathway for drug activity in both diseases.

\section{Vasoconstrictors}

$\alpha$-adrenoceptor agonists reduce the severity of a common cold illness significantly $(86,87\}$, showing that vasodilatation, and not edema formation, is the major cause of nasal blockage. Intranasal application has a definitely better therapeutic index than oral administration, but a nasal spray should only be used for 1-2 weeks due to the risk of rhinitis medicamentosa. 


\section{Anticholinergics}

Intranasal ipratropium bromide is effective in stopping watery nasal discharge in the initial phase of a cold by blocking the cholinergic innervation of the submucosal glands (88). This is clear evidence that the rhinorrhea in common cold is a glandular product and not plasma exudation. Ipratropium bromide has no effect on viscous mucopurulent secretions (88).

\section{Antihistamines and NSAIDs}

Described above.

\section{Combined therapy}

Probably the most effective treatment of common cold consists of a combination of antiviral and antimediator drugs, as proposed by Gwaltney (87). In a study of volunteers with experimentally induced RV infection combined treatment with intranasal interferon- $\alpha$, intranasal ipratropium bromide and oral naproxen significantly reduced the viral titer and the overall cold symptoms (87). A fortune is still awaiting the inventor of an effective treatment for the common cold.

\section{Common cold viruses as triggers of asthma exacerbations}

\section{Magnitude of the problem}

Clinical experience has indicated that a viral airway infection preceeds the large majority of acute episodes of wheeziness in infants and children, and that it is also an important cause of exacerbations of asthma in adults (90).

The study of the association between viral airway infections and wheezy episodes/exacerbations of asthma has been hampered by the lack of sensitive diagnostic tests for virus infection (91). Recently, the very sensitive PCR and RT-PCR technique have been used in two studies.

Johnston and coworkers (92) studied 108, 9-11-year-old children with asthma. In more than $80 \%$ of the episodes with wheezing and reduced peak flow, PCR on respiratory secretions was positive for virus, and this was picornavirus, i.e. RV, in two-thirds of the cases. Thus, this study showed that at least $80 \%$ of reported exacerbations of asthma in school children are associated with an upper airway infection, caused mainly by RV.

Nicholson and coworkers (93) studied the role of a common cold in excerbations of asthma in 138 adults in a longitudinal study. The patients reported clinical colds in
$80 \%$ of episodes with asthma symptoms. A virus was identified in $57 \%$ of subjects with symptomatic colds, and in these cases RV was found in $64 \%$ and coronavirus in $30 \%$. Thus, at least half the asthma exacerbations were associated with a virus infection, predominantly with RV. The authors conclude that acute airway infections may be as commonly linked to exacerbations of asthma in adults as in children.

In conclusion recent studies, using the highly sensitive $P C R$ technique, have indicated that a viral airway infection, especially with RV, is an important precipitator of asthma episodes, even more important than believed earlier.

\section{Lower airways in naturally acquired colds}

While studies have shown convincingly that colds can increase asthma severity, there is little information on the direct effect of a naturally acquired cold virus infection on the immunopathology of the lower airways.

Trigg and coworkers (94) studied whether naturally acquired colds increase lower airway inflammation in nonasthmatic subjects. Twenty subjects $/ 12$ normal persons and eight atopics and four of these rhinitics) had a bronchoscopy before and during a cold. A viral infection was diagnosed in eight of the subjects /six normal and two atopics). In bronchial biopsies, during colds, eosinophils and $\mathrm{CD}^{+} \mathrm{T}$ cells increased significantly, and neutrophils increased in bronchial washings.

The authors conclude that lower airway inflammation is present in subjects with a cold, and that many subjects with symptoms, traditionally thought to indicate upper airway infection, have evidence of lower airway inflammation. However, the atopic subjects in this study had more activated eosinophils and less positive virological tests than the nonatopic controls, which raises a question about the validity of the study. Symptoms of a virus cold and of allergic rhinitis are similar, and allergic subjects may have reported symptoms of allergic inflammation as "a cold".

\section{Lower airways in experimental rhinovirus infection}

A number of studies have dealt with experimental RV infection, lower airway inflammation, and bronchial responsiveness. In these studies virus inoculation has been performed using standard methods. The inoculum is dripped or sprayed into the nasal cavity which makes bronchial deposition of the virus unlikely. RV $16(39,40,94-96)$ and RV 39 (97) have been used. 


\section{Enhanced bronchial inflammation}

Bronchoscopy studies during an experimental RV infection have shown an increase in mucosal $\mathrm{CD}_{3}{ }^{+}, \mathrm{CD}_{4}{ }^{+}$and $\mathrm{CD}^{+}$cells $(41)$, in epithelial eosinophils $(41)$, and in the concentration of ECP in induced sputum (97). Interestingly, the epithelial eosinophil numbers were elevated for a prolonged period in asthmatic volunteers (41), and there seems to be a positive correlation between the concentration of sputum-ECP and the change in bronchial responsiveness $\left(\mathrm{PC}_{20}\right.$ histamine) (99). While these results indicate that a viral infection can activate eosinophils in vivo, RV has little effect on eosinophil activation in vitro (100).

Based on these studies it has been hypothesized that an immunologic response, involving $T$ cells and eosinophils, may be responsible for the virus-induced increase in airway responsiveness in asthmatics $(41)$, described below.

Also the concentration of IL-6 and IL-8 in induced sputum is increased during an experimental RV infection (97).

It is difficult to explain why RV, which primarily infect the upper airways and cause rhinitis symptoms, induce a $T$-cell/eosinophil inflammation in the bronchi but not in the nose.

\section{Increased bronchial response to antigen}

Busse and colleagues (101-103) performed segmental bronchial provocation with allergen during bronchoscopy in volunteers with and without an experimental RV infection. During the viral infection there was an increased symptom response to the allergen challenge (both early and late response), an increased level of histamine and protein and an increased number of eosinophils in bronchoalveolar lavage fluid. The authors conclude that these data show an increase in inflammatory response during the RV infection, which indicates that RV upregulates the inflammatory response to allergen, and this may be due to an increased generation of cytokines. The findings imply that viral infections and allergies may have synergistic effects on lower airway inflammation that increases the likelihood of wheezing.

Increased bronchial response to histamine and methacholine Asthma symptoms are closely associated with bronchial hyperresponsiveness, making measurement of $\mathrm{PC}_{20}$ or $\mathrm{PD}_{20}$ to inhaled histamine or methacholine useful parameters for studying the link between common cold and asthma.
Normal subjects

Skoner et al. (98) and Gern et al. (96) did not find any change in nonspecific bronchial responsiveness during an experimental RV infection in normal volunteers.

\section{Allergic rhinitis}

Lemanske and colleagues (95) studied 10 ragweed-allergic subjects outside the pollen season. An RV infection resulted in a significantly increased bronchial responsiveness to histamine. Gern and coworkers (96) obtained a similar result in 18 subjects with a positive skin test to ragweed, cat or housedust mite but without rhinitis symptoms. In contrast Skoner et al. (98), in a large study of 46 subjects with seasonal allergic rhinitis, studied outside the pollen season, were unable to find any significant change in bronchial responsiveness during a $\mathrm{RV}$ infection. Thus, the results are conflicting, and this is probably due to differences in the selection of patient populations (mild or severe rhinitis).

\section{Allergic asthma}

While Halperin and coworkers $(104)$ found increased responsiveness to histamine in only four out of 22 asthma subjects after experimental RV infection, three other studies of asthma patients have all shown a significant reduction in $\mathrm{PC}_{20}$ or $\mathrm{PD}_{20}$ to inhaled histamine or methacholine $(40,41$, 97). The increase in bronchial responsiveness in these studies has been modest, which may be due to the selection of patients. For safety reasons, only patients with mild asthma have been studied.

Understandably, asthma patients who increase their bronchial sensitivity to nonspecific stimuli also do so to a specific challenge with allergen, especially demonstrated by an increased late-phase responsiveness (95).

\section{Mechanisms by which viruses precipitate asthma}

A number of mechanisms have been proposed to explained how a common cold can induce asthma, but so far no explanation is satisfactory. In principle, a common cold can induce asthma exacerbations in two different ways: 1) directly by a virus infection of the lower airways, and 2) indirectly by an infection, limited to the upper airway, which by immunological and neurogenic mechanisms induces lower airway inflammation, hyperresponsiveness and asthma symptoms. 


\section{Does rhinovirus infect the lower airways?}

Clearly, this is an important question for the understanding of the link between a common cold and asthma. Most evidence, so far, has been equivocal on the question (4). It has been difficult to determine whether virus growth occurs in the bronchi because of the problem of obtaining lower airway specimens that are not contaminated with nasopharyngeal secretions during sampling (104).

Gern and coworkers (105) used RT-PCR to identify RV in bronchoalveolar lavage cells from volunteers inoculated intranasally with RV. The RT-PCR was positive in eight of eight inoculated volunteers, and negative in the controls. Although these results suggest that $R V$ can infect the lower airways, it is necessary to remember that RT-PCR is an extremely sensitive test and that contamination from the upper airways cannot completely be excluded. The final proof will be to show RV infection of bronchial epithelial cells by in situ hybridization as was done for nasal epithelial cells by Arruda and coworkers (17). A recent study of in situ hybridization has shown rhinovirus signals in five of 10 bronchial biopsies, strongly suggesting that rhinoviruses do replicate in the lower airways /Sebastian L. Johnston, personal communication).

\section{Direct effect of lower airway infection on asthma}

Theories have been advanced, placing the bronchial epithelial cell in a central position. However, there are major problems with most of the hypotheses, described below. First, it is doubtful whether bronchial epithelial cells are infected by RV. Secondly, considering the minor cytopathic effect of RV on the epithelial lining in the nose and on epithelial cells in vitro, it seems highly unlikely that there are any marked structural and functional changes in the bronchial epithelium.

\section{Cytokines}

Epithelial cells are able to secrete a broad array of cytokines, as discussed earlier. In vitro studies indicate that RV induces secretion of IL-1, IL-6, IL-8, IL-1 1, RANTES and GM-CSF from epithelial cells (105). IL-11 is secreted in large amounts and may have a direct effect on bronchial hyperresponsiveness (106). Respiratory viruses have the ability to induce the release of cytokines also from other cell types. Balfour-Lynn and coworkers (107) reported that tumor necrosis factor- $\alpha$, a proinflammatory cytokine, produced primarily by mononuclear phagocytes, was detectable in nasopharyngeal secretions in over three-quarters of infants with wheezing illness.

\section{Mediators}

Epithelial cells also produce biochemical mediators, such as products of 15 -lipoxygenase activity 1 15-HETEs and leukotriene $\mathrm{B}_{4}$ ) which can directly contract bronchial smooth muscles (108).

\section{Bronchodilator factor}

It has been reported that the epithelium is a source of a regulator protein (endogenous bronchodilator factor) with a protective role that maintains bronchial patency. Also it has been speculated that epithelial damage may reduce the synthesis of this protein resulting in bronchoconstriction $\{109\}$.

\section{Neurogenic inflammation}

Based on rodent studies, it has been hypothesized that epithelial damage, by loss of neutral endopeptidase and reduced breakdown of neuropeptides such as substance $P$, results in the development of neurogenic inflammation. However, neurogenic inflammation has not been described in humans.

\section{Vagal reflex}

It seems reasonable to assume that disruption of the surface epithelium may induce airway hyperresponsiveness by exposing sensory nerve endings to irritants and inflammatory mediators, so the afferent fibers cause increased vagal activity leading to enhanced bronchoconstriction.

\section{Antigen absorption}

It has long been believed that epithelial stripping aids penetration of antigens into the mucous membrane, but Greiff and coworkers (78) have now shown clearly that mucosal absorption of macromolecules is not increased during an infection with coronavirus.

\section{Indirect effect of upper airway infection on asthma}

In theory, an indirect effect from an infection, limited to the upper airways, could be mediated by the following mechanisms: 1) impaired nasal physiology; 2) a nasobronchial reflex; 3) aspiration of infectious secretions; and 4) absorption of cytokines and mediators, causing recruitment and activation of immune cells, which may have an effect not only in the nose but also in the lower airways and in other parts of the body.

Emphatically, we find the last possibility most likely. A systemic effect of an RV cold on host defense factors is supported by the observation that a common cold not only induces an exacerbation of asthma, but can also reactivate a 
herpes infection on the lip. It has been described above that a common cold can reduce the T-cell response and cytokine formation (44).

Whether RV induces bronchoconstriction by direct infection or as an indirect consequence of upper airway infection, it can be hypothesized that it is the inflammatory response to the cold virus that is responsible for triggering virusinduced exacerbation of asthma and not a direct cytopathologic effect on bronchial cells, and this is similar to the hypothesis advanced earlier for the nasal cold symptoms.

As described earlier, other viruses (influenza-, parainfluenza- and adenovirus|, having a pronounced cytophalogic effect, may induce asthma symptoms by other mechanisms.

\section{Does allergy predispose to common cold?}

\section{Increased frequency}

As mentioned earlier, allergen exposure upregulates the expression of ICAM-1 on the surface of the airway epithelium $\{22\}$, and one can therefore speculate that allergen-exposed allergic patients may have an increased suceptibility to RV infections. However, there are no data in support of this hypothesis, and it is not common clinical experience that allergic patients have more colds than normal persons. As it can be difficult to distinguish between an attack of allergic rhinitis and a viral infection, modem and sensitive diagnostic tests (PCR and RT-PCR) are necessary in studies of the frequency of $\mathrm{RV}$ infections in atopic and nonatopic individuals.

\section{Increased severity}

It can also be speculated that allergic rhinitis, associated with upregulation of ICAM-1 and with the presence of inflammatory cells in the surface epithelium, leads to more cold symptoms during a virus infection because it is amplified by ongoing inflammation.

Some support for this hypothesis comes from a study by Bardin and coworkers (19), who inoculated 11 normal volunteers (five atopic and six asthmatic patients) with RV. The authors concluded that the results "suggest heightened suceptibility to the detrimental effects of a cold in the atopic/asthmatic patients".

Hinriksdottir (110) studied 64 patients with allergic rhinitis and 23 nonallergic individuals who recorded symptoms of upper airway infections for 1 year. There was no difference between the two groups concerning the number of upper airway infections or the duration of the disease. Doyle and coworkers $(77)$ found that experimentally induced RV colds are clinically similar in normal and allergic subjects.

In summary, the above studies indicate that allergic rhinitis cannot be considered to increase the frequency or the severity of upper respiratory infections.

\section{Prevention and treatment of common cold- induced asthma}

\section{Reduced transmission}

When mothers, exposed to a child with a fresh cold at home, regularly dipped their fingers in $2 \%$ aqueous iodine, the number of new colds was reduced by $67 \%(6)$. Another study of the hand-contact route of cold transmission was performed under natural conditions in asthmatic children (111). One group of children was trained to avoid selfinoculatory (finger/nose) behavior and they were then compared with untrained controls. Following the training period, the groups were followed for several months during which time the trained group had significantly less selfinoculatory behavior, fewer viral respiratory infections and fewer attacks of asthma.

These data indicate that patients with asthma may be able to reduce the number of colds and of acute exacerbations. Washing hands after an infectious contact can be recommended, as well as avoiding finger-to-eye and finger-to-nose contact. Alternatively, right-handed asthmatics could touch their eyes and nose only with the left hand, adapting the practice of using a "clean hand" for this purpose and a "dirty hand" for contact with the surroundings.

It is possible that an asthmatic mother having a small child may, in the future, be able to reduce the number of asthma exercabations by use of an antiviral hand lotion or an intranasal interferon- $\alpha$ spray, when the child get cold symptoms. Finally, kindergartens are not suitable places for patients with severe asthma, children and adults.

\section{Corticosteroids}

It is general practice, recommended in international consensus reports $(112)$, to treat severe exacerbations of asthma with corticosteroids. A rationale for doing this is a reduced sensitivity of $\mathrm{T}$ cells to corticosteroid treatment during a common cold, recently shown by Vianna and coworkers $(44)$. 
Most, but not all, placebo-controlled trials have shown a beneficial effect of corticosteroids in acute severe asthma (113). Although airway infections, including common colds, are known to be important causes of asthma exacerbations, there does not seem to be any placebocontrolled study on the use of corticosteroids in this specific situation. A Medline search of published articles (1 June 1998/ gave the following number of publications: asthma 51972; asthma and corticosteroids 1956; asthma and common cold 89; asthma and common cold and corticosteroids 3 .

In an open study of preschool children who suffered from repeated asthma attacks, related to upper airway infections, Brunette and coworkers (114) found that a short burst of oral prednisone $(1 \mathrm{mg} / \mathrm{kg}$ ), given as soon as the first symptoms of an infection appeared, resulted in a significant decrease in the number of wheezing days and visits to the emergency room.

Recently, Doull and coworkers (115) performed a doubleblind study of the prophylactic effect of inhaled beclomethasone dipropionate (400 $\mu \mathrm{g} /$ day) on wheezing episodes associated with viral infection in 104 children aged 7-9 years. Although there was a significant increase in $\mathrm{FEV}_{1}$ and in methacholine $\mathrm{PD}_{20}$ the authors conclude that the treatment offered no clinically significant benefit on the wheezing episodes.

\section{Conclusions}

Studies of the link between the common cold and asthma are few and our knowledge is remarkably insufficient, considering the important clinical significance of this issue. It is clear that RV causes little damage to epithelial cells in the nose, and it is not definitely proven that the viruses infect the lower airways. It remains to be established, therefore, whether a RV infection causes wheezing by a direct infection of the lower airways or by alternate mechanisms through which upper airway infections can cause changes in lower airway function. It is hypothesized that virus-induced generation of cytokines, mainly by epithelial cells, amplifies the T-cell-driven eosinophil inflammation in asthma, but it is unclear how the vinus-induced inflammation, characterized by a Th1-type cytokine response, enhances inflammation in asthma, characterized by a Th2-type cytokine response. Furthermore, it is not in accordance with an important role played by cytokines in the production of cold symptoms that corticosteroids have no or little effect on the nasal symptoms of a cold. Clinical experience shows that corticosteroids have a beneficial effect on cold-induced asthma exacerbations, but placebo-controlled studies have not been performed. Finally, intervention studies are needed to show whether attempts of stopping virus transmission to asthma patients can reduce their number of colds and of asthma exacerbations.

\section{References}

1. Corne JM, Holgate ST. Mechanisms of virus induced exacerbations of asthma. Thorax 1997;52:380-389.

2. Johnston S. Vinuses and asthma. Eur $]$ Allergy Clin Immunol 1997;53:922-932.

3. Folkert G, Busse WW, Nijkamp FP, Sorkness $\mathrm{R}$, Gern JE. Virus-induced airway hyperresponsiveness and asthma. Am Rev Respir Crit Care Med 1998;157:1708-1720.

4. Gwaltney JM Jr, Ruckert RR. Rhinovirus. In: Richman DD, Whitley RJ, Hayden FG, editors. Clinical virology. New York: Churchill Livingstone, 1997:1025-1047

5. Rossman $M G$, Palmenberg AC. Conservation of the putative receptor attachment site in picornavinuses. Virology 1988;164:373-382

6. Hendley JO, Gwaltney JM Jr. Mechanisms of transmission of rhinovinus infection. Epidemiol Rev 1988;10:242-258.

7. Dingle JH, Badger GF, Jordan WS Jr. Illness in the home. A study of 25,000 illnesses in a group of Cleveland families. Cleveland: The Press of Western Reserve University, 1964.
8. Hendley JO, Gwaltney JM Jr, Jordan WS Jr. Rhinovirus infections in an industrial population. $\Gamma$. Infections within families of employees during two fall peaks of respiratory illness. Am / Epidemiol 1969;89:184-196

9. Gwaltney IM Jr, Moskalski PB, Hendley JO. Hand-to-hand transmission of colds. Ann Intern Med 1978;88:463.

10. Gwaltney JM Jr, Moskalski PB, Hendley JO. Interruption of experimental rhinovirus transmission. I Infect Dis 1980;142:811.

11. Gwaltney JM Jr, Hendley JO. Transmission of experimental rhinovirus infection by contaminated surfaces. Am I Epidemiol $1982 ; 116: 828$.

12. Hayden GF, Hendley OJ, Gwaltney IM Jr. The effect of placebo and virucidal paper handkerchiefs on viral contamination of the hand and transmission of experimental rhinoviral infection. / Infect Dis $1985 ; 152: 403$.
13. Gern JE, Galagan DM, Jarjour NN, Dick EC, Busse WW. Detection of rhinovirus RNA in lower airway cells during experimentally induced infection. Am / Respir Crit Care Med 1997;155:1159-1161.

14. Ostberg B, Winther B, Mygind N. Cold air induced rhinorrhea and high-dose ipratropium. Arch Otorhinolaryngol 1987;113:160-162.

15. Winther B, Gwaltney JM Jr, Mygind N, Tumer RB, Hendley JO. Sites of rhinovirus recovery after point-inoculation of the upper airways. JAMA 1986;256:1763-1767.

16. Arruda $E$, Mifflin TE, Gwaltney JM, Winther B, Hayden FG. Localization of thinovinus replication in vitro with in situ hybridization. I Med Virol 1991;34:38-44.

17. Arnuda E, Boyle TR, Winther B, Pevear DC, Gwaltney JM Jr, Hayden FG. Localization of human rhinovirus replication in the upper respiratory tract by in situ hybridization. I Infect Dis 1995;171:1329-1333. 
18. Tumer RB, Hendley JO, Gwaltney IM Ir. Shedding of infected ciliated epithelial cells in rhinovirus colds. I Infect Dis $1982 ; 145: 849$

19. Bardin PG, Johnston SL, Sanderson G, et al. Detection of rhinovirus infection of the nasal mucosa by oligonucleotide in situ hybridization. Am / Respir Cell Mol Biol 1994;10:207-213.

20. Turner RB, Winther B, Hendley JO. Mygind $\mathrm{N}$, Gwaltney IM Jr. Sites of virus recovery and antigen detection in epithelial cells during experimental rhinovirus infection. Acta Otolaryngol (Stockh) ${ }_{1984 ;}$ Suppl. 413:9-14.

21. Greve JM, Davis G, Mayer AM. The major human rhinovirus receptor is ICAM-1. Cell 1989;56:839.

22. Ciprandi G, Pronzato C, Ricca V, Bagnasco $\mathrm{M}$, Canonica $\mathrm{GW}$. Evidence of intracellular adhesion molecule- 1 expression on nasal epithelial cells in acute rhinoconjunctivitis caused by pollen exposure. / Allergy Cin Immunol 1994;99:738-746.

23. Winther B, Greve JM, Gwaltney JM Jr, et al. Surface expression of ICAM-1 on epithelial cells in the human adenoid. IInfect Dis 1997;176:523-525.

24. Campell AM, Vignola AM, Chanez P. HLADR and ICAM-1 expression on bronchial epithelial cells in asthma and chronic bronchitis. Am Rev Respir Dis 1993;148:689-694.

25. Winther B, Gwaltney JM Jr, Hendley JO. Respiratory virus infection of monolayer cultures of human nasal epithelial cells. Am Rev Respit Dis 1990;141:839-845.

26. Hoorn B, Tyrrell DA. Effects of some viruses on ciliated cells. Am Rev Respir Dis 1966;93:156-161.

27. Becker S, Soukup J, Yankaskas IR. Respiratory syncytial virus infection of human primary nasal and bronchial epithelial cell cultures and bronchoalveolar macrophages. Am I Respir Cell Mol Biol 1992;6:369-374.

28. Hilding A. The common cold. Arch Otolatyngol 1930;12:133-150.

29. Winther B, Brofeldt S, Christensen B, Mygind N. Light and scanning electron microscopy of nasal biopsy material from patients with naturally acquired cornmon colds. Acta Otolaryngol (Stockh) 1984;97:309-318.

30. Winther B, Brofeldt S, Grønborg H, Mygind N, Pedersen M, Vejlsgaard R. Study of bacteria in the nasal cavity and nasopharynx during naturally ascuired common colds. Acta Otolaryngol (Stockh) 1984;98:315-320.
31. Carson JL, Collier AM, Hu SS. Acquired ciliary defects in nasal epithelium of children with acute viral upper respiratory infections. $N$ Engl $/$ Med 1985;312:463-468.

32. Persson CGA. Asthma the important questions: epithelial cells, barrier functions and shedding-restitution mechanisms. Am I Respir Crit Care Med 1999 (in press).

33. Pedersen $M$, Sakakura $Y$, Winther B, Brofeldt $S$, Mygind N. Nasal mucociliary transport, number of ciliated cells, and beating pattern in naturally acquired common colds. Eur Respir $/$ 1983;64(Suppl. 128):355-364.

34. Bryan WTK, Bryan MP, Smith CA. Human ciliated epithelial cells in nasal secretions. Ann Otol Rhinol Laryngol 1964;73:474.

35. Afzelius B. Ultrastructure of human nasal epithelium during an episode of coronavirus infection. Virch Arch 1994;424:295-300.

36. Winther B, Farr B, Turner RB, Hendley $1 O$, Gwaltney IM Jr, Mygind N. Histopathologic examination and enumeration of polymorphonuclear leukocytes in the nasal mucosa during experimental rhinovirus colds. Acta Otolaryngol (Stockh) 1984; Suppl. 413:19-24.

37. Fraenkel DJ, Bardin PG, Sanderson G, Lampe F, Johnston SL, Holgate ST. Immunohistochemical analysis of nasal biopsies during thinovirus experimental colds. Am I Respir Crit Care Med 1994;150:1 130-1136.

38. Naclerio RM, Proud D, Lichtenstein LM, et al. Kinins are generated during experimental rhinovirus colds. I Infect Dis 1988;157:133142.

39. Levandowski RA, Ou DW, Jackson GG. Acute-phase decrease of T-lymphocyte subsets in rhinovirus infection. I Infect Dis 1986;153:743-748.

40. Cheung D, Dick EC, Timmers MC, de Klerk EPA, Spaan WJM, Sterk PJ. Rhinovirus inhalation causes long-lasting excessive airway narrowing in response to methacholine in asthmatic subjects in vivo. Am I Respir Crit Care Med 1995; 152:14901496.

41. Fraenkel DI, Bardin PG, Sanderson G, Lampe F, Johnston SL, Holgate ST. Lower airways inflammation during rhinovirus colds in normal and asthmatic subjects. Am I Respir Crit Care Med 1995;151:879-886.

42. Winther B, Innes DF, Bratsch J, Hayden FG. Lymphocyte subsets in the nasal nasal mucosa and peripheral blood during experimental rhinovirus infection. Am J Rhinol 1992;6:149-156.
43. Skoner DP, Whiteside TL, Wilson JW, Doyle WJ, Herberman RB, Fireman P. Effect of rhinovirus 39 infection on cellular immune parameters in allergic and nonallergic subjects. I Allergy Clin Immunol 1993;92:732-743.

44. Vianna EO, Westcott I, Martin RI. The effects of upper respiratory infection on $T$ cell proliferation and steroid sensitivity in asthmatics, / Allergy Clin Immunol 1998; 102:592-597.

45. Gwaltney Jr JM, Hendley JO, Turner RB, et al. Symposium on rhinovirus pathogenesis. Acta Otolaryngol (Stockh) 1984; Suppl. 413:5-45.

46. Winther $B$. The effect on the nasal mucosa of respiratory viruses (common cold). Dan Med Bull 1994;41:193-204.

47. Subauste MC, Jacoby DB, Richards SM, Proud D. Infection of a human respiratory epithelial cell line with rhinovirus. Induction of cytokine release and modulation of susceptibility to infection by cytokine exposure. / Clin Invest 1995;96:549-557.

48. Zhu Z, Tang W, Gwaltney JM Jr, Elias JA. Rhinovirus stimulation of interleukin- 8 in vivo and in vitro: role of NF-kappaB. Am I Physiol 1997;273:L814-L824.

49. Turner RB. Rhinovirus infection of human embryonic lung fibroblast induces the production of a chemoattractant for polymorphonuclear leukocytes. I Infect Dis 1988;157:346-350.

5o. Röseler S, Holtappels G, Wagenmann M, Bachert C. Elevated levels of interleukins ILibeta, IL- 6 and IL-8 in naturally aequired viral rhinitis. Eur Arch Otorhinolaryngol 1995;252 (Suppl. 1):S61-S63.

51. Noah TL, Henderson FW, Wortman IA, et al. Nasal cytokine production in viral acute upper respiratory infection of childhood. I Infect Dis 1995;171:584-792.

52. Turner $\mathrm{RB}$, Weingand $\mathrm{KW}$, Yeh $\mathrm{CH}$, Leedy DW. Association between interleukin- 8 concentration in nasal secretions and severity of symptoms of experimental rhinovirus colds. Clin Infect Dis 1998;26:840-846.

53. Choi AMK, Jacoby DB. Influenza virus A infection induces interleukin-8 gene expression in human airway epithelial cells. FEBS Lett 1992;309:327-329.

54. Kenney IS, Baker C, Welch MR, Altman LC. Synthesis of interleukin-1 alpha, interleukin-6, and interleukin-8 by cultured human nasal epithelial cells. I Allergy Clin Immunol 1994;93:1060-1067. 
55. Proud D, Gwaltney JM Ir, Hendley JO, Dinarello CA, Gillis S, Schleimer RP. Increased levels of interleukin-1 are detected in nasal secretions of volunteers during experimental rhinovirus colds. Infect Dis 1994;169:1007-1013

56. Zhu Z, Tang W, Ray A, et al. Rhinovirus stimulation of interleukin. 6 in vivo and in vitro: evidence for NFKB-dependent transcriptional activation. / Clin Invest 1996;97:421-430

57. Cheung D, Hiemstra PS, Dick EC, de Klerk EPA, Sterk PJ. Effects of experimental rhinovirus infection on IL- 8 in nasal washings in asthmatic subjects in vivo. Eur Respir / 1994;7:481s.

58. Teran L, Johnston S, Shute I, Church $M$, Holgate S. Increased levels of interleukin-8 in nasal aspirates of children with viral associated asthma. I Allergy Clin Immunol 1994:93:272.

59. Lau L, Come I, Scott S, Davies R, Friend E, Howarth P. Nasal cytology in the common cold. Am I Respir Crit Care Med 1996;153:A697.

60. Muraguchi A, Hirano T, Tang B, et al. The essential role of $B$ cell stimulatory factor 2 [BSF-2/IL-6] for the terminal differentiation of B cells. I Exp Med 1988;167:332-344.

61. Linden $M$, Greiff $L$, Andersson $M$, et al. Nasal cytokines in common cold and allergic rhinitis. Clin Exp Allergy 1995;25:166-172

62. Proud D, Naclerio RM, Gwaltncy JM Jr, Hendley IO. Kinins are generated in nasal secretions during natural rhinovirus colds. I Infect Dis 1990;161:120-123.

63. Proud D, Reynolds CJ, Lacapra S, KageySobotka A, Lichtenstein LM, Naclerio RM. Nasal provocation with bradyldnin induces symptoms of rhinitis and a sore throat. Am Rev Respir Dis 1988;137:613-616.

64. Eggleston PA, Hendley JO, Gwaltney JM Jr. Eggleston AW, Leavell BS Ir. Histamine in nasal secretions. Arch Allergy Appl Immunol 1978;57:193-200.

65. Naclerio RM, Proud D, Kagey-Sobotka A, Lichtenstein LM, Hendley JO, Gwaltney JM Ir. Is histamine responsible for the symptoms of thinovinus colds? A look at the inflammatory mediators following infection. Pediatr Infect Dis J 1988;7:218222.

66. Igarashi Y, Skoner DP, Fireman P, Kaliner MA. Analysis of nasal secretions during experimental rhinovirus upper respiratory infections. I Allergy Clin Immunol 1993;92:722-731.

67. Smith MB, Feldman W. Over-the-counter cold medications. A critical review of clinical trial between 1950 and 1991. JAMA 1993;269:2258-2263.
68. Eccles R, van Cauwenberge P, Tetzloff W, Borum P. A clinical study to evaluate the efficacy of the antihistamine doxylamine succinate in the relief of runny nose and sneezing associated with upper respiratory tract infection. I Pharm Pharmacol 1995;47:990-993.

69. Gwaltney IM Jr, Park J, Paul RA, Edelman DA, O'Connor RR, Tumer RB. Randomized controlled trial of clemastine fumarate for treatment of experimental rhinovirus colds Clin Infect Dis 1996;22:656-662.

70. Gwaltney JM Jr, Druce HM. Efficacy of brompheniramine maleate treatment for rhinovirus colds. Clin Infect Dis 1997;25:1188-1194.

71. Bisgaard H. Olsson P, Bende M. Effect of leukotriene $\mathrm{D}_{4}$ on nasal mucosal blood flow, nasal airway resistance and nasal secretion in humans. Clin Allergy 1986;16:289-298.

72. Lundgren $\mathrm{DD}_{\mathrm{t}}$ Shelhammer $\mathrm{TH}$. Pathogenesis of airway mucus hypersecretion. I Allergy Clin Immunol 1990;85:399-417.

73. Doyle WI, Boehm S, Skoner DP. Physiologic response to intranasal dose-response challenge with histamine, methacholine, bradykinin, and prostaglandin in adult volunteers with and without nasal allergy. I Allergy Clin Immunol 1990;86:924-935.

74. Sperber SJ, Hendley JO, Hayden FG, Riker DK, Sorrentino IV, Gwaltney GM Jr. Effects of naproxen on experimental rhinovirus colds. Ann Intern Med 1992;117:37.

75. Winther B, Mygind N. Placebo-controlled trial of the effect of ibuprofen on the symptoms of naturally acquired common cold.1999 (in preparation).

76. Gronborg H, Borum P, Winther B, Mygind N. Nasal methacholine and histamine reactivity during a common cold. Eur J Respir Dis 1983;64(Suppl. 128):406-408.

77. Doyle W], Skoner DP, Seroky JT, Fireman P, Gwaltney IM. Effect of experimental rhinovirus 39 infection on the nasal response to histamine and cold air challenges in allergic and nonallergic subjects. I Allergy Clin Immunol 1994;93:534-542.

78. Greiff L, Andersson $\mathrm{M}$, Åkerlund A, et al. Microvascular exudative hyperresponsiveness in human coronavirusinduced common cold. Thorax 1994;49:121127.

79. Gwaltney JM Jr, Phillips CD, Miller RD, Riker DK. Computed tomographic study of the common cold. $N$ Eng1 $/ \mathrm{Med}$ 1994:330:25-30.

8o. Hayden FG, Albrecht JK, Kaiser DL Gwaltney JM Jr. Prevention of natural colds by contact prophylaxis with intranasal alphaz-interferon. $N$ Engl I Med $1986 ; 314: 71$
81. Hayden FG, Gwaltney IM Ir. Intranasal interferon-alpha2 treatment of experimental rhinoviral colds. I Infect Dis 1984;150:174180.

82. Farr BM, Gwaltney JM Jr, Hendley JO, et al. A randomized controlled trial of glucocorticoid prophylaxis against experimental rhinovirus infection. / Infect Dis 1990;162:1173-1177.

83. Puhakka T, Makela MJ, Malmström K, et al. The common cold: effect of intranasal fluticasone propionate treatment. / Allergy Clin Immunol 1998;101:726-731.

84. Gustafson LM, Proud D, Hendley IO, Hayden FG, Gwaltney JM Jr. Oral prednisone therapy in experimental rhinovirus infections. I Allergy Clin Immunol 1996;97:1009-1014.

85. Grønborg H, Winther B, Brofeldt S, Mygind $N$. Effects of oral norephedrine on common cold symptoms. Rhinology 1983;21:3-12.

86. Åkerlund A, Klint T, Olén L, Rundcrantz H. Nasal decongestant effect of oxymethazoline in the common cold: an objective dose-response study in 106 patients. I Laryngol Otol 1989;103:743-746.

87. Sperber SI, Sorrentino JV, Riker DK, Hayden FG. Evaluation of an alpha agonist alone and in combination with a nonsteroidal antiinflammatory agent in the treatment of experimental rhinovirus colds. Bull NY Acad Med 1989;65:145-160.

88. Borum P, Olsen L, Winther B, Mygind N. Ipratropium nasal spray: a new treatment for rhinorrhea in the common cold. Am Rev Respir Dis 1981;123:418-420.

89. Gwaltney JM Jr. Combined antiviral and antimediator treatment of thinovirus colds. I Infect Dis $1992 ; 166: 776-782$.

9o. Pattemore PK, Johnston SL, Bardin PG Viruses as precipitants of asthma symptoms. I. Epidemiology. Clin Exp Allergy 1992;22:325-336.

91. Minor TE, Dick EC, Baker JW, Ouellette J, Cohen M, Reed CE. Rhinovirus and influenza type A infections as precipitants of asthma. Am Rev Respir Dis 1976;113:149153.

92. Johnston S, Pattemore PK, Sanderson $G_{\text {, et }}$ al. Community study of role of viral infections in exacerbations of asthma in 911-year-old children. Br Med J 1995;310:1225-1229.

93. Nicholson KG, Kent J, Ireland DC. Respiratory viruses and exacerbations of asthma in adults. Br Med/ 1993;307:982986.

94. Trigg $\mathrm{Cl}$, Nicholson $\mathrm{KG}$, Wang $\mathrm{JH}$, et al. Bronchial inflammation and the common cold: a comparison of atopic and non-atopic individuals. Clin Exp Allergy 1996;26:665. 
95. Lemanske RF, Dick EC, Swenson CA, Vrtis RF, Busse WW. Rhinovirus upper respiratory infection increases airway hyperreactivity and late asthmatic reactions. $/$ Clin Invest 1989;83:1-10.

96. Gern JE, Calhoun W, Swenson C, Shen G, Busse WW. Rhinovirus infection preferentially increases lower airway responsiveness in allergic subjects. Am J Respir Crit Care 1997;155:1872-1876.

97. Grünberg K, Timmers MC, Smits $\mathrm{HH}_{i}$ et al. Effect of experimental rhinovirus 16 on airway hyperresponsiveness to histamine and interleukin-8 in nasal lavage in asthmatic subjects in vivo. Clin Exp Allergy 1997;27:36-45.

98. Skoner DP, Doyle WJ, Seroky J, Van Deusen MA, Fireman P. Lower airway responses to rhinovirus 39 in healthy allergic and nonallergic subjects. Eur Respir I 1996;9:1402-1406.

99. Grünberg K, Smits HH, Timmers $M C_{\text {, }}$ et al. Experimental rhinovirus 16 infection. Effects on cell differentials and soluble markers in sputum in asthmatic subjects. Am J Respir Crit Care Med 1997;156:609616.

100. Handzel ZT, Busse WW, Sedgwick IB, et al Eosinophils bind rhinovirus and activate virus-specific T cells. / Immunol 1998;160: 1279-1284.

101. Busse WW, Calhoun WJ, Dick EC. Effect of an experimental rhinovirus 16 infection on airway mediator response to antigen. Int Arch Allergy Immunol 1992;99:422-424.
102. Calhoun WJ, Dick EC, Schwartx LB, Busse WW. A common cold, rhinovirus 16, potentiates airway inflammation after segmental antigen bronchoprovocation in allergic subjects. I Clin Invest 1994;94:2200-2208.

103. Calhoun WJ, Swenson CA, Dick EC, Schwartz LB, Lemanske RF, Busse WW. Experimental rhinovirus 16 infections potentiates histamine release after antigen bronchoprovocation in allergic subjects. Am Rev Respir Dis 1991;144:1267-1273.

104. Halperin SA, Eggleston PA, Hendley JO, et al. Pathogenesis of lower respiratory tract symptoms in experimental rhinovirus infection. Am Rev Respir Dis 1983;128:806.

105. Gern JE, Lemanske JrRF, Busse WW. The role of rhinoviruses in virus-induced asthma. In: Marone G, Austen KF, Holgate ST, Kay AB, Lichtenstein LM, editors. Asthma and allergic diseases. San Diego: Academic Press, 1998:293-307.

106. Einarsson O, Geba GP, Zhu Z, Landry M, Elias JA. Interleukin-1 1: stimulation in vivo and in vitro by respiratory vinusus and induction of airways hyperresponsiveness. J Clin Invest 1996;97:915-924.

107. Balfour-Lynn L, Valman $H$, Wellings $R$, et al Tumour necrosis factor- $\alpha$ and leukotriene $\mathrm{E}_{4}$ production in wheezy infants. Clin Exp Allergy 1994;24:121-126.
108. Shannon V, Chanez P, Bousquet I, et al. Histochemical evidence for induction of arachidonate 15 -lipoxygenase in airways disease. Am Rev Respir Dis 1993;147:10241028.

109. Butler GB, Adler KB, Evans JN. Modulation of rabbit airway smooth muscle responsiveness by respiratory epithelium. Am Rev Respir Dis 1987;135:1099-1097.

110. Hinriksdottir I, Melen I. Allergic rhinitis and upper respiratory tract infections. Acta Otolaryngol (Stockh) 1994;Suppl. 515:3032.

111. Corley DL. Prevention of postinfectious asthma in children by reducing selfinoculatory behavior. I Pediatr Psychol $1987 ; 12: 519-531$.

112. McFadden JrER. Dosages of corticosteroids in asthma. Am Rev Respir Dis $1993 ; 147: 1306-1310$.

113. Engel T, Heinig JH. Glucocorticoid therapy in acute severe asthma - a critical review. Eur Respir I 1991;4:881-889.

114. Brunette MG, Lands L, Thibodeau LP. Childhood asthma: prevention of attacks with short-term corticosteroid treatment of upper airway respiratory tract infection. Pediatrics 1988;81:624-629.

115. Doull IJM, Lampe FC, Smith S, Schreiber J, Freezer NJ, Holgate ST. Effect of inhaled corticosteroids on episodes of wheezing associated with viral infection in school age children: randomized double blind placebo controlled trial. Br Med / 1997;315:858-862. 